\title{
Endothelial Dysfunction through Oxidatively Generated Epigenetic Mark in Respiratory Viral Infections
}

\author{
Spiros Vlahopoulos ${ }^{1, *(\mathbb{D}}$, Ke Wang ${ }^{2,3}$, Yaoyao Xue ${ }^{2,3}, \mathrm{Xu}_{\text {Zheng }}{ }^{2,3}$, Istvan Boldogh ${ }^{2}$ and Lang Pan ${ }^{2,4, *}$ \\ 1 Horemeio Research Laboratory, First Department of Pediatrics, National and Kapodistrian, \\ University of Athens, 11527 Athens, Greece \\ 2 Department of Microbiology and Immunology, University of Texas Medical Branch at Galveston, \\ Galveston, TX 77555, USA; kewang@UTMB.EDU (K.W.); \\ yaxue@UTMB.EDU or xueyy459@nenu.edu.cn (Y.X.); zhengx807@nenu.edu.cn (X.Z.); \\ sboldogh@utmb.edu (I.B.) \\ 3 Key Laboratory of Molecular Epigenetics of Ministry of Education, School of Life Science, \\ Northeast Normal University, Changchun 130024, China \\ 4 Department of Physiology, School of Basic Medicine, Xiangya Medical School, Central South University, \\ Changsha 410078, China \\ * Correspondence: sblachop@med.uoa.gr (S.V.); lapan@UTMB.EDU (L.P.)
}

Citation: Vlahopoulos, S.; Wang, K.; Xue, Y.; Zheng, X.; Boldogh, I.; Pan, L. Endothelial Dysfunction through Oxidatively Generated Epigenetic Mark in Respiratory Viral Infections. Cells 2021, 10, 3067. https://doi.org/ 10.3390/cells10113067

Academic Editor: Konstantin G. Birukov

Received: 13 September 2021 Accepted: 3 November 2021 Published: 7 November 2021

Publisher's Note: MDPI stays neutral with regard to jurisdictional claims in published maps and institutional affiliations.

Copyright: (c) 2021 by the authors. Licensee MDPI, Basel, Switzerland. This article is an open access article distributed under the terms and conditions of the Creative Commons Attribution (CC BY) license (https:/ / creativecommons.org/licenses/by/ $4.0 /)$.

\begin{abstract}
The bronchial vascular endothelial network plays important roles in pulmonary pathology during respiratory viral infections, including respiratory syncytial virus (RSV), influenza A(H1N1) and importantly SARS-Cov-2. All of these infections can be severe and even lethal in patients with underlying risk factors.A major obstacle in disease prevention is the lack of appropriate efficacious vaccine(s) due to continuous changes in the encoding capacity of the viral genome, exuberant responsiveness of the host immune system and lack of effective antiviral drugs. Current management of these severe respiratory viral infections is limited to supportive clinical care. The primary cause of morbidity and mortality is respiratory failure, partially due to endothelial pulmonary complications, including edema. The latter is induced by the loss of alveolar epithelium integrity and by pathological changes in the endothelial vascular network that regulates blood flow, blood fluidity, exchange of fluids, electrolytes, various macromolecules and responses to signals triggered by oxygenation, and controls trafficking of leukocyte immune cells. This overview outlines the latest understanding of the implications of pulmonary vascular endothelium involvement in respiratory distress syndrome secondary to viral infections. In addition, the roles of infection-induced cytokines, growth factors, and epigenetic reprogramming in endothelial permeability, as well as emerging treatment options to decrease disease burden, are discussed.
\end{abstract}

Keywords: endothelial cells; oxidative stress; pulmonary edema; respiratory syncytial virus; influenza H1N1; SARS-Cov-2; respiratory distress syndrome; gene expression

\section{Introduction}

The endothelium is a semi-permeable barrier that separates any given tissue from blood or lymph. The endothelium nourishes every tissue and extends into all organs by forming a single-cell layer lining the inner surface of blood arterioles, capillaries, and post-capillary venules and lymphatic vessels. It covers thousands of square meters (up to $7000 \mathrm{~m}^{2}$ ) within an adult human. It forms the greatest surface where large numbers of physiological processes take place. The endothelial vascular network regulates exchange of fluid, electrolytes, various macromolecules (plasma proteins, hormones, inflammatory mediators), and controls trafficking of leukocyte immune cells. In addition, the endothelium maintains blood fluidity, regulates blood flow, and responds to signals triggered during oxygenation, hypoxia, and inflammation. Remarkably, endothelial cells can remain in a resting state over long periods of time, while keeping their ability to respond and regulate diverse processes when they are activated [1]. 
Dysfunction of the vascular endothelial barrier in the lungs can lead to acute respiratory distress syndrome (ARDS). ARDS is an extremely severe, frequently fatal condition characterized by fluid accumulation (edema) in the lungs due to a leaky endothelium under inflammatory conditions, induced by viral, bacterial or fungal infection. ARDS represents a great challenge for several patient populations. Presently, there is no efficient preventive measure or a means to reverse this fluid accumulation; essentially, supportive clinical care in terms of artificial ventilation is the standard treatment. In uninfected lungs, electrolytes and small polypeptides cross the intravascular space to the interstitial space via intercellular gaps between capillary endothelial cells and are returned by the lymphatics to the circulation. These electrolytes do not enter the alveoli in normal conditions due to the tightness of the epithelium in the alveoli [2].

\section{Endothelial Cells}

Endothelial cells (ECs) comprise the inner surface of blood vessels as a single-cell layer that has the function of a semi-permeable barrier between circulating blood and underlying tissue; ECs have a similar function in lymphatic vessels [3,4]. ECs regulate vascular function in terms of blood flow, blood fluidity, and vascular permeability, and are implicated in pathological manifestations after viral infections, control of immunity, inflammation, and leukocyte recruitment. Importantly ECs largely influence the spectrum of tissues that a virus can reach via circulation. ECs are effectors of the host response to viral infections; however, it must be noted that activation of host response to viruses occurs both in infected as well as uninfected cells, due to the diffusion of second messengers across intercellular gap junctions, and the secretion of paracrine mediators [5-8].

ECs regulate leukocyte traffic, vascular tone and permeability, and coagulation, and participate in control of allergic inflammation through the expression of soluble mediators and adhesion molecules in response to stimuli such as the cytokine interleukin-4 (IL-4) $[9,10]$. Expressed molecules also include: selectins E and P, intercellular adhesion molecules 1 and 2 (ICAM-1, ICAM-2), vascular adhesion molecule (VCAM), inflammatory cytokines interleukin-1 (IL-1) and -6 (IL-6), chemokines C-X-C motif chemokine ligand 8 (CXCL8, IL-8) and RANTES (Regulated upon Activation, Normal T Cell Expressed and Presumably Secreted), prostacyclin-2, endothelium-derived relaxing factor, nitric oxide, elements of local renin-angiotensin system, angiopoietins, tissue plasminogen activator, and endothelial plasminogen activator inhibitor [9,11-14]. Both in normal and inflamed tissues, ECs express CD antigens (cluster of designation), including CD31, CD34, CD309/Flk-1, CD202b/Tie2, CD144/VE-Cadherin, CD105/endoglin, CD146, acting as receptors or ligands $[15,16]$.

The role of ECs in allergic responses that involve vascular damage and angioedema has been investigated in a clinical trial showing the role of ECs in chronic urticaria (registered with identification code NCT03443362), an inflammatory disorder that is driven by mast cells. EC dysfunction has a central role in this disorder, especially in the context of expression of adhesion molecules, increased vascular permeability, angiogenesis, increase in markers of coagulation and fibrinolysis, and importantly, increases in IL-4 and IL-6 [17].

\subsection{The Pulmonary Endothelial Cell}

Pulmonary ECs are an essential component of the gas exchange machinery of the lung alveolus, which can be divided into macrovascular and microvascular endothelial cells $[18,19]$. These cells are particularly interesting due to their potential for a number of important pathologic consequences upon infection, and during the process of recovery from infections or inflammation [20]. For instance, transdifferentiation of ECs or weakening of the endothelium, can occur. The latter can result from increased contractility and the loosening of intercellular tight junctions, which are both induced by inflammatory cytokines [21].

Abnormal activation of the host response to structures conserved among infectious agents and to known allergens activates the lung endothelium to elicit an angiogenic 
response associated with activation of T-helper cell type-2 (Th2)-driven inflammation [22]. Endothelial cells, as well as epithelial cells, actively participate in both innate and adaptive immune responses, which are crucially involved in the pathogenesis of allergic disorders; these responses are characterized by the expression and secretion of inflammatory mediators such as tumor necrosis factor alpha (TNF $\alpha)$ and by cytokines of the Th2 state such as interleukins-4 (IL-4) and-13 (IL13) [23].

In bronchi, endothelial and epithelial cells are also involved in pulmonary pathology [24]. The involvement of ECs in pulmonary pathology of viral infections is an active field of research. It has produced some controversial results yet promises to deliver important answers regarding the pathobiology of infectious disease. Specifically, endothelium has been shown to possess a key role in lung pathogenesis from viral infections such as influenza, respiratory syncytial virus (RSV), and recently SARS-CoV-2. A well-studied example is bronchiolitis associated with RSV infection [25].

\subsection{Permeability of the Alveolar Endothelium during Respiratory Viral Infections}

One potentially severe form of respiratory complication is manifested upon infection of bronchial endothelial cells. The endothelial loss of tight junctions (TJ) leading to edema in ARDS often causes alveolar epithelial damage due to the cells' capacity to support RSV, influenza or CoV-2 replication. The loss of cell-to-cell contact in the endothelium is linked to death of alveolar epithelial cells, changes in extracellular matrix (ECM) protein components and their contact with endothelial and epithelial cells, and changes in the communication of both epithelium and endothelium with immune cells. Of note, TJs also modulate cellular polarity, activate a variety of intracellular signals, and control the transcellular transport across the endothelium and the epithelium by altering expression of transport proteins and ion channels. Lung inflammation is the key reason for TJ breakdown in the endothelium and epithelium $[2,26,27]$.

Inflammation in the alveoli occurs prior to the development of endothelial breakdown of TJs and is associated with excessive changes in electrolytes and protein permeability [26]. In RSV, influenza, and CoV-2-infected experimental mouse models of acute innate inflammation and also in humans, this transition is characterized by excessive neutrophil influx, activation of macrophages, and exacerbated expression of type CC, CXC chemokines (IL-8, monocyte chemoattractant protein-1 (MCP-1 or CCL2), macrophage inflammatory protein1 (MIP-1 or CCL3), cytokines (e.g., TNF- $\alpha$ ), interleukins (IL-1 $\beta$, IL-6), interferons (INF $\gamma$, IFN $\alpha$ and INF $\lambda$ ), and growth factors (e.g., granulocyte colony-stimulating factor, G-CSF). The reason is that most alveolar epithelial and endothelial cells express receptors for these soluble mediators and respond by amplifying the expression of these mediators [27]. For example, IL-1 $\beta$ increases endothelial and epithelial permeability via rat sarcoma virus homolog family, member A (RhoA)/integrins-mediated epithelial transforming growth factor beta (TGF- $\beta$ ) release. TGF- $\beta$ signaling has been shown to induce post-translational modifications (e.g., phosphorylation) of adherent junction proteins and formation of actin stress fibers in endothelial cells in vitro [28]. IL-1 $\beta$ also enhances fluid transport across the human distal lung epithelium in vitro [29]. TNF- $\alpha$ strongly decreases the trans-endothelial electrical resistance across human pulmonary arterial endothelial cells; this effect is independent from myosin light chain phosphorylation catalyzed by either myosin light chain kinase or Rho serine-threonine kinase, but dependent on p38 mitogen-activated protein kinase activation [30]. The underlying mechanisms of capillary endothelial and epithelial barrier alterations point to apoptosis-dependent and apoptosis-independent mechanisms [31]. To this end, TNF- $\alpha$ also decreases expression of TJ proteins (ZO-1, claudin 2-4-5) as well as $\beta$-catenin in pulmonary arterial endothelium and also alveolar epithelium [32-34], which can be exacerbated by IFN- $\gamma$ [35].

TNF- $\alpha$ also enhances human pulmonary microvascular endothelial permeability by altering the actin cytoskeleton via activation of PKC, increase of MAPK activity in a RhoA/ROCK-dependent manner, and inhibition of the Rho-dependent myosin-lightchain phosphatase $[30,36,37]$. TNF- $\alpha$, IL- $1 \beta$ and IL- 6 can upregulate trypsin expression 
in arterial endothelial cells, which may lead to the loss of zonula occludens-1 (ZO-1) and vascular hyperpermeability via protease-activated receptor-2 [38]. IL-4 and IL-13 decrease the expression of ZO-1 and occludin and lower the capacity of repair in the pulmonary epithelium, which also leads to compromise in arterial endothelial barrier function [39].

\section{Respiratory Viruses and Their Effects on the Bronchial Endothelium}

We next compare infections from RSV, influenza H1N1 and SARS-CoV-2 and describe their effects in the activation of inflammatory pathways that are implicated in bronchial pathology. The descriptions of these three viruses linked to dysfunction of the endothelial cells is not meant to be exhaustive, but instead provides examples of the severity of the threat for morbidity or loss of life that is associated with infections that compromise the function of the endothelial cells and can lead to dysregulation of the barrier function. We note that human rhinoviruses, parainfluenza viruses, metapneumovirus, respiratory adenovirus, bocaviruses, coronaviruses, middle-east respiratory syndrome virus (MERS), and severe acute respiratory syndrome virus (SARS) are also accountable for over three million deaths worldwide and are responsible for multiple outbreaks in recent times [40].

\subsection{Respiratory Syncytial Virus}

Infections by RSV are a formidable threat for certain groups of patients, especially newborns and elderly [25,41]. It is a single stranded, negative-sense enveloped RNA virus belonging to the Orthopneumovirus genus of thePneumoviridae family [42]. RSV replicates in the nasopharynx and then spreads within the epithelium of bronchi and bronchiole by cell-to-cell and producing clinical features including bronchiolitis and pneumonia [43-45]. RSV also productively infects non-epithelial cells; thus, it been isolated from alveolar endothelium, myocardial tissue, central nervous system, cerebrospinal fluid, endocrines and liver, during severe disease and sudden infant death [46-49]. There is no effective treatment or vaccine available for RSV; palivizumab (a humanized monoclonal antibody) is the only RSV immunoprophylaxis approved for use in specific high-risk pediatric populations [50]. The therapy is mostly supportive care combined with symptomatic treatments including modalities such as bronchodilators, epinephrine, corticosteroids, hypertonic saline, and/or supplemental oxygen [51,52].

Newborns cannot be expected to mount a sufficiently strong secretion of IFNs to respond against RSV, while the elderly do not respond well to vaccinations in general [53]. There are vaccine candidates under development, yet it remains a major challenge to immunize certain population categories [54]. It is imperative that therapies are developed to protect patients that either have not been vaccinated or cannot mount an optimal immune response to RSV. RSV infection causes respiratory symptoms that may encompass the lower respiratory tract, culminating in bronchiolitis, which in severe cases results in necrosis and the sloughing of epithelial cells into the airways, airway mucus, edema, and peribronchiolar inflammation, cumulatively resulting in airway obstruction [55-57]. Severe bronchiolitis is associated with the manifestation of asthma in later life [57]. Epithelial cells express cytokines IL-33, IL-25, and thymic stromal lymphopoietin (TSLP), as well as the innate immune cell-derived cytokine high mobility group box 1 (HMGB1), which activate group 2 innate lymphoid cells (ILC2). This signaling promotes the progression of T-helper type 2-mediated pulmonary disease, thus explaining the association of RSV with asthma in later life.

In vitro and in vivo experiments show that during RSV infection, epithelial cells infected with RSV express and secrete IL-1 $\alpha$, which activates vascular endothelial cells to express increased cell surface ICAM-1, and to a lesser extent, vascular adhesion molecule1 (VCAM-1) and E-selectin [58]. RSV induces expression of MIP-1 $\alpha$ in epithelial cells of the alveoli and bronchioles, as well as in adjoining capillary endothelium [59]. Adhesion experiments using polymorphonuclear leukocytes (PMN) verified an increased ICAM-1-dependent adhesion rate of PMN co-cultured with RSV-infected endothelial cells. Furthermore, the increased adhesiveness resulted in an enhanced transmigration rate of 
PMN [60]. ICAM-1 expression on RSV-infected endothelial cells may contribute to the enhanced accumulation of PMN into the bronchoalveolar space. The virus-induced ICAM-1 upregulation was dependent on the activity of protein kinase $\mathrm{C}$, protein kinase A, phosphatidylinositol 3-kinase (PI3K), and p38 mitogen-activated protein kinase (MAPK) [60].

In lung alveoli, a gradient of CXCL8 is the most likely chemo-attractant for the neutrophils that migrate from the systemic circulation into the alveolar space [61]. Neutrophils function by releasing reactive oxygen species (ROS) and extracellular traps, undergoing degranulation and phagocytosis, and by recruiting other cell types to the site of infection such as alveolar macrophages, dendritic cells, and T-cells [62]. However, soluble endothelial cell adhesion molecules (sCAMs), such as sICAM-1, can be measured in the systemic circulation, indicating that the currently postulated neutrophil influx into the lungs should rather be regarded as a neutrophil efflux from the vasculature, involving substantial neutrophil-endothelial interactions. Endothelial cells become activated upon RSV infection, driving a 'pro-adhesive state' for circulating neutrophils with upregulation of endothelial ICAM-1. During RSV lower respiratory tract infections, different subsets of immature and mature neutrophils are present in the bloodstream, parallel with upregulation of integrins, lymphocyte-function associated (LFA)- 1 and macrophage (Mac)- 1 antigen, serving as ICAM-1 ligands [61].

RSV infection induces ROS generation, activates mitogen- and stress-activated kinases1 (MSK1)-phospho-Ser-276 v-relreticuloendotheliosis viral oncogene homolog A (RelA) pathway required for cytokine expression [63]. Aero-allergens and respiratory viruses stimulate toll-like receptor (TLR) signaling, producing oxidative injury and inflammation [64]. Repetitive exacerbations produce complex mucosal adaptations, cell-state changes, and structural remodeling. These structural changes produce substantial morbidity, decrease lung capacity, and impair quality of life. Repetitive activation of innate signaling pathways produces a form of epigenetic 'training' in the cell nucleus, to induce adaptive epithelial responses [64].

\subsection{Influenza Virus and SARS-CoV-2}

Influenza viruses have a single negative-stranded segmented RNA genome; deadliest in history is H1N1, an Alphainfluenzavirus of the family Orthomyxoviridae [65,66]. SARS-CoV-2 in contrast, the causative agent of the COVID-19 pandemic, belongs to the positive-strand RNA viruses of the genus Beta coronavirus [67]. Both viruses constitute very significant health burdens worldwide, due to the lack of effective treatments, and are still under research for the generation of vaccines that will offer lasting protection against emerging variants $[68,69]$. In influenza virus infection, pulmonary endothelial cells play a central role in regulating both innate immune cell recruitment as well as innate cytokine and chemokine production [4]. In victims of the 2009 pandemic influenza A/H1N1 infection, tissues of bronchial mucosa, lung, myocardium, gastrocnemius, and liver that were investigated by light microscopy and transmission electron microscopy, viral particles were found in all samples, frequently located in endothelium, epithelium, and muscle cells [70]. Cultured ECs respond to infection and iron incubation with increased production of IL-6. Iron, the generation of intracellular hydroxyl radical and NF- $\mathrm{kB}$ activity are essential in cellular activation, suggesting that ROS generated in the Haber-Weiss reaction are essential in invoking an immunological response to infection by ECs [71].

In patients who died from SARS-CoV-2 or influenza (H1N1)-associated respiratory failure, the histologic pattern in the peripheral lung was diffuse alveolar damage with perivascular T-cell infiltration. The lungs from patients with COVID-19 also showed distinctive vascular features, consisting of severe endothelial injury associated with the presence of intracellular virus and disrupted cell membranes. Histologic analysis of pulmonary vessels in patients with COVID-19 showed widespread thrombosis with microangiopathy. Alveolar capillary micro-thrombi were 9 times as prevalent in patients with COVID-19 as in patients with influenza $(p<0.001)$. In lungs from patients with COVID-19, the amount of new vessel growth-predominantly through a mechanism of intussusceptive 
angiogenesis-was 2.7 times as high as that in the lungs from patients with influenza $(p<0.001)$ [72].

Although respiratory viruses initially infect the airway epithelium, it is a compromise in vascular integrity that causes alveolar damage [4]. Indeed, the compromise in vascular integrity distinguishes influenza H1N1 from SARS-CoV-2 infections, and this divergence in effects can be attributed to difference in the patterns of expression and secretion of inflammatory mediators. The main difference between influenza and SARS-CoV-2 infections is the ability of SARS-CoV-2 to elicit dysfunction of the blood vessels. This difference can be attributed to a divergent expression of signaling molecules that cause the pathology that involves blood vessels. A comparison between immunological factors produced during the influenza and SARS-CoV-2 infection suggests that although both infections raise levels of T-helper type I mediators, SARS-CoV-2 also distinctly increases T-helper type II (Th2) mediators (IL-4, IL-5, IL-10, IL-13), as well as the allergy mediator [73]. In contrast, H1N1 severe cases show high expression of surfactant protein D at the alveolar epithelium [73]. H1N1 infections have shown more efficient activation of reparative macrophages of the M2 subtype [74]. This might suggest a more efficient repair capacity for the H1N1-infected lung.

One hypothesis is that severe SARS-CoV-2-driven pneumonia causes respiratory failure via pulmonary microthrombi and endothelial dysfunction [75]. A considerable body of evidence suggests that SARS-CoV-2, unlike other related viruses, infects and replicates within ECs, which may explain a significant portion of the observed clinical pathology $[76,77]$. On the contrary, certain data that show an inability of SARS-CoV-2 to directly infect and lyse endothelial cells without angiotensin-converting enzyme-2 (ACE2) expression explain the lack of vascular hemorrhage in COVID-19 patients and indicate that the endothelium is not a primary target of SARS-CoV-2 infection [78]. Although the detection of SARS-CoV-2 has not been singularly linked to bronchiolitis, with the exception of necrotizing bronchiolitis [79], it has been proposed that co-infections of SARS-CoV2 with other viruses, most notably RSV, are associated with a severe course of bronchiolitis in patients [80]. Furthermore, SARS-CoV-2 can directly infect engineered human blood-vessel organoids in vitro. EC involvement was demonstrated across vascular beds of different organs in a series of patients with COVID-19 and SARS-CoV-2 can directly infect engineered human blood-vessel organoids in vitro [81].

The binding site of the SARS-CoV-2 viral spike protein on the surface of cells is the receptor "angiotensin converting enzyme 2 (ACE2)", which functions to protect against hypertension, cardiovascular and lung diseases, and diabetes mellitus [82]. In an experimental setting, loss of ACE2 function in the mouse lung during endotoxin inhalation led to release of inflammatory chemokines such as C-X-C motif chemokine 5 (CXCL5), macrophage inflammatory protein-2 (MIP2), C-X-C motif chemokine 1 (KC), and pluripotent cytokine TNF- $\alpha$ from airway epithelia, increased neutrophil infiltration, and exaggerated lung inflammation and injury [83]. By immunohistochemistry, flow cytometry and RNA sequencing, the lung could show expression of ACE2, mainly in alveolar macrophages, and subsets of type II alveolar epithelial cells [84-88].

SARS-CoV-2 infection can result in diverse, multiorgan pathology, the most significant being in the lungs (diffuse alveolar damage in its different phases, micro-thrombi, bronchopneumonia, necrotizing bronchiolitis, viral pneumonia), heart (lymphocytic myocarditis), kidney (acute tubular injury), central nervous system (micro-thrombi, ischemic necrosis, acute hemorrhagic infarction, congestion, and vascular edema), lymph nodes (hemophagocytosis and histiocytosis), bone marrow, and vasculature (deep vein thrombosis) [79].

\section{RSV, H1N1 and SARS-CoV-2 Infections and Oxidative Stress}

Endothelial dysfunction is tightly correlated with oxidative stress, which represents unifying concepts for the underlying permeability changes and its pathophysiology marked by pulmonary morbidity and mortality $[89,90]$. Therefore, inflammatory cells are implicated in the induction of endothelial dysfunction, either directly from ROS generated by 
respiratory viral infections or indirectly by inflammatory mediators. The sub-molecular mechanisms of ROS generation are well established, and multiple sources are involved in generating oxidative stress during viral infections (Figure 1). These include mitochondria, peroxisomes, endoplasmic reticulum associated cytochrome oxidoreductases in nonimmune cells, and NADPH oxidase and xanthine oxidase in immune cells, as well as myeloperoxidase released from neutrophils $[83,91,92]$. In particular, RSV infection increases cellular ROS levels via NADPH oxidases and mitochondria, which are paralleled with the downregulation of superoxide dismutase, 1,3, catalase, and glutathione-S-transferase expression via degradation of the transcription factor NF-E2-related factor 2 [91-93]. Similarly, H1N1 infections increase ROS levels derived from multiple sources as determined by increases in oxidative metabolites such as 8-hydroxydeoxyguanosine (8-oxoGua), malondialdehyde, 2-isoprostane, 7-ketocholesterol, 7-beta-hydroxycholesterol, and carbonyl compounds as well as the activity of Nrf2, which controls the expression of enzymes that participate in the defense against oxidation [94]. In experimental animal models and cell culture infections with SARS-CoV-2, increases in ROS levels were observed through the activation of oxidoreductases, mitochondrial dysfunction and perturbation of cellular antioxidant defenses, similar to those of RSV or influenza infections [95-97]. Excess ROS generated by mitochondria is the primary cause of oxidative stress and is considered to initiate and exacerbate inflammation and chronic endothelial dysfunction [97]. Consequently, mitochondrial oxidative stress could prime endothelial cells to acquire a pro-thrombotic and pro-inflammatory phenotype, predisposing patients to thromboembolic and vasculitic events and to disseminated intravascular coagulopathy [97]. This implies a pivotal role played by oxygen centered free radicals in the pathogenetic mechanism of RSV-, H1N1-and SARS-CoV-2-induced diseases, in that its availability would tune the oxidant state and consequent damage $[93,94,98]$.

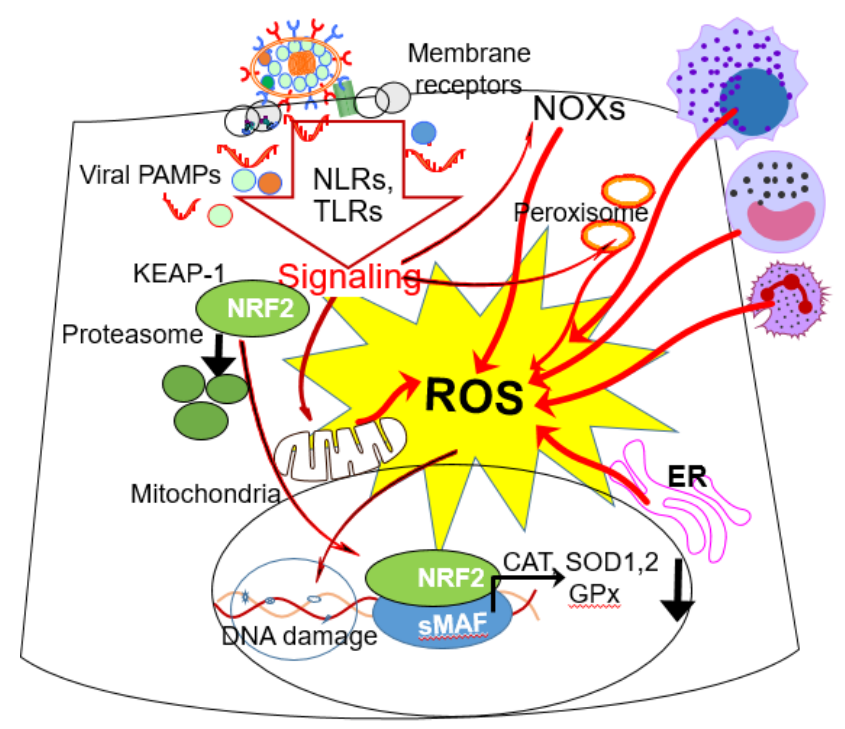

Figure 1. Cellular sources of ROS in respiratory viral infections. Activation of receptors liganded by RSV, influenza and SARS-CoV-2 envelope proteins and the recognition of viral PAMPs by intracellular sensors (NLRs, TLRs) trigger signaling pathways, leading to activation of oxidoreductases located in cell membranes, endoplasmic reticulum, peroxisomes, and mitochondria. NADPH oxidases (NOXs) are the primary enzyme complexes in nearly all cell types, particularly in granulocytes and macrophages, along with oxidoreductases in mitochondrial complex I and II, which partially oxidize oxygen molecules to generate superoxide anion $\left(\mathrm{O}_{2}{ }^{\bullet-}\right) \cdot \mathrm{O}_{2}{ }^{\bullet-}$ via Fenton and/or Haber-Weiss reactions are converted into hydroxyl radical $\left({ }^{\bullet} \mathrm{OH}\right)$. The highly reactive ${ }^{\bullet} \mathrm{OH}$ reacts with proteins, lipids and DNA. ROS themselves, but particularly peroxidation of polyunsaturated fatty acids, trigger nuclear translocation of nuclear factor erythroid 2-related factor 2 (NRF2), which heterodimerizes with small musculoaponeurotic fibrosarcoma (MAF) transcription factor and binds the cis-acting 
enhancer antioxidant response element (ARE), leading to the expression of antioxidant enzymes, including $\mathrm{Cu} / \mathrm{Zn}$-superoxide dismutase (SOD1), glutathione peroxidases (GPXs) and catalase (CAT). However, in RSV and SARS-CoV-2infected cells and lungs there is a progressive decrease in levels of NRF2 via increased protein ubiquitination and its degradation through a proteasomal pathway [93,99-101]. Although ROS generation in RSV, SARS-CoV-2 infected cells is similar, it seems that NRF2 primarily modifies influenza A entry and replication [102]. In addition to the above-described pathways, activated monocytes and polymorphonuclear cells, in particular, neutrophils, have been shown to produce ROS. Abbreviations: NLR, nucleotide-binding oligomerization domain-like receptors; TLR, TOLL-like receptors, PAMP, pathogen-associated molecular patterns; NOX, nicotinamide adenine dinucleotide phosphate (NADPH) oxidase; ER, endoplasmic reticulum.

\section{Gene Expression Driving Pulmonary Pathologies via Dysregulation of Bronchial Endothelial Cells}

Infected cells secrete soluble mediators such as inflammatory cytokines IL-1 $\beta$, IL-6, and TNF, which in turn stimulate neighboring cells to express cascades of inflammatory mediators and adhesion molecules that enable exacerbation of inflammation, ROS generation and its associated pathological sequelae [82]. Endothelial cells, in response to viral infection and inflammation, express and secrete CXCL8, which activates neutrophil chemotactic movement and extravasation to exacerbate inflammation [103-105].

The inducible expression of cytokines and chemokines by inflammatory stimuli has been previously characterized. In particular, inflammatory stimuli induce a number of cell surface receptors and intracellular receptors, which in turn activate signaling cascades that culminate in the activation and nuclear translocation of transcription factors. These factors, bound to their DNA binding site, recruit transcriptional initiation and elongation components to activate expression of inflammatory genes in response to stimuli. The activated genes also encode several proteins that program the termination of inflammation to reestablish physiological cellular function. The return of cellular functions enables restoration of tissue homeostasis that is essential for the health of the organism [106].

Specifically, viral PAMPs through signaling cascades, and other inflammatory stimuli including ROS induce expression of cytokines and chemokines through activation of transcription factor binding on the promoter region of their genes [94,102,107]. In the activation of inflammatory gene expression, one of the best characterized transcription factors is nuclear factor kappa B (NFkB), which is activated after mediators of tissue stress, such as bacterial lipopolysaccharide, damage-associated molecules, ROS or inflammatory cytokines and cytokines that bind to their receptors at the cell surface [106,108]. These ligand-receptor interactions activate signaling cascades that culminate in the activation of gene expression by $\mathrm{NF}_{\kappa} \mathrm{B}$ (and other transcription factors including STATs, AP1, and CREB), which, in turn, activates inflammatory genes such as chemokine IL-8 (CXCL8). IL-8 is secreted, generating concentration gradients at the host tissue that lead to the recruitment of neutrophils by chemotaxis $[107,109]$. Mechanistically, NFkB bound to its cis element, interacts with the transcriptional elongation complex, which consists of cyclin-dependent kinase 9 and bromodomain-containing protein 4 (BRD4). BRD4 facilitates phosphorylation of RNA polymerase II and regulates its enzymatic processivity and RNA splicing functions. Recent data also show that the association of RelA (NFKB' catalytic subunit) with BRD4 induces its histone acetyl transferase activity acetylating histone $\mathrm{H} 3$ on Lys 122, which is a modification that leads to the destabilization of nucleosomes. Consequently, together this activity mediates cytokine production, neutrophilia, leukocytic infiltration, and clinical manifestations of disease [64].

In RSV, H1N1 or SARS-CoV-2 infection, clusters of NFkB target genes are expressed, driving the main part of pathological changes in tissues [64,110-115]. Respiratory viral infections result in inflammation and oxidative injury, as well as feedback-mediated enhancement of the expression of inflammatory genes. Although ROS are required for activation of NFKB and initiation of host antiviral responses, it has been shown that deregulation of the control of oxidant stress has a role in disease pathology, leading to the 
proposal of interventions that target the emergence of aberrantly increased ROS [116,117]. Therefore, the use of radical scavengers such as $N$-acetylcysteine and vitamin $\mathrm{C}$, as well as inflammasome inhibitors, have been proposed as a method to inhibit the pathological effects of these viral infections [93,117-119].

Henceforth, it can be concluded that viral infection of airway epithelial cells, including type II cells, induces expression of inflammatory mediators, which are secreted and exposed at the cell surface. The mediators activate phenotypes of inflammation in all types of neighboring cells, regardless of the presence (or absence) of effective viral infections. This is especially true for pulmonary endothelial cells, which undergo extensive inflammatory changes in gene expression and phenotypes, which thereby intensifies the recruitment of inflammatory cells, like neutrophils, and damages host tissue [120]. Experimentally, activated vascular endothelial cells become a source of inflammatory cytokines and ROS, contributing to the development of coagulopathy, systemic sepsis, and cytokine storm.

\section{Unifying Approach to Ameliorate Endothelial Dysfunction via DNA Occupancy of Transcription Factors}

Because oxidative stress is the link to numerous pathologies caused by RSV, influenza, or SARS-CoV-2 infections, in theory, the use of antioxidants such as (vitamins E, C, SH group donors (e.g., $N$-acetyl cysteine), iron chelating agents (deferoxamine)- or activators of NRF2-driven gene expression, could be useful in decreasing expression of specific proinflammatory mediators and help recovery of experimental animals and patients from respiratory viral infections $[91,93,99,100,117,119]$. However, these attempts resulted in only partial successes to inhibit steps in the process of inducible expression of cytokines and chemokines and endothelial dysfunction [117,121,122].

Interaction of ROS with DNA produce modification to purine and/or pyrimidine bases and DNA strands (apurinic/apyrimidinic sites and DNA single- and double-strand breaks), which need to be repaired to maintain genome integrity. Of these, the most frequent is a purine oxidation product, 7,8-dihydro-8-oxodezoxyguanine (8-oxoGua), which is thought to be a pre-mutagenic lesion [123]. Under physiological conditions, it is removed via basespecific DNA repair enzymes primarily by 8-oxoguanine DNA glycosylase (OGG1) and to a smaller extent also by Nei-like glycosylases (e.g., NEIL1, NEIL-2, human homolog of E. coli Nei-like glycosylase 1and 2) from double and single stranded DNA, respectively [124]. The generated apurinic/apyrimidinic (AP) site is tailored by AP endonuclease1/redox effector factor-1 (APE1/Ref1) to form polymerase-ready 3'OH residues [124,125]. The generated DNA strand gaps are filled via the short and/or the long-patch repair sub-pathways [126].

Recent reports have documented that 8-oxoGua and AP-site, in gene regulatory elements of various inflammatory, hypoxia response genes and some proto-oncogenes, can modulate transcription [127-133]. For these reasons, 8-oxoGua(s) in a transcription start site (TSS) adjacent promoter sequences is considered as an epigenetic-like mark [129,133]. Binding of OGG1 to 8-oxoGua (with or without excision) in the gene regulatory region facilitates binding of transcription factors, including NFKB, as depicted in Figure 2A-C [132,134,135]. This 8-oxoGua enrichment in promoter regions is not unique to cytokine (e.g., TNF $\alpha$ )exposed cells as promoters of hypoxia-inducible genes, including vascular endothelial growth factor and endonuclease III-like protein 1, which contains potential guaninequadruplex forming sequences, which also acquire 8-oxoGua $[128,129,136,137]$. 


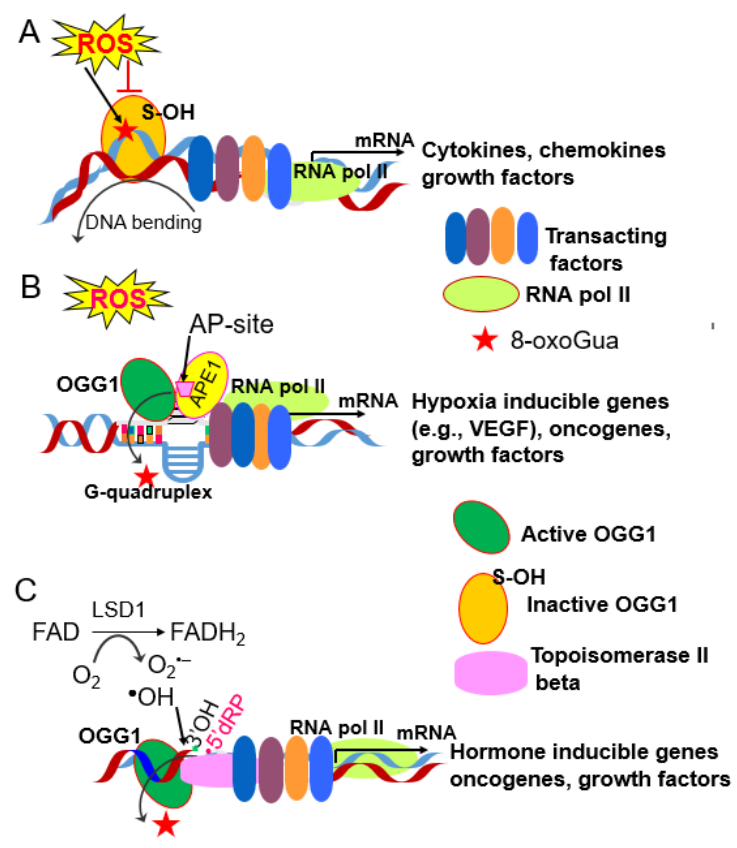

Figure 2. Models for OGG1-8-oxoGua-dependent gene expression. (A) Viral infection-induced ROS or those generated by cytokine exposure oxidatively modify guanine to 8-oxoGua and inactivate OGG1' glycosylase activity by reversible oxidation at cysteine residues (cysteine-sulfenic acid). Oxidatively disabled OGG1 flips 8-oxoGua into its active-site pocket, interacts with the opposing cytosine and results in the conformational change of the DNA helix, which favors TFs DNA occupancy. (B) OGG1-8-oxoGua driven gene expression under hypoxic conditions. Guanines in gene promoters with G-quadruplexes are highly sensitive to ROS and are oxidized to 8-oxoGua under tissue hypoxia, caused by SARS-CoV-2, RSV, or H1N1 infections during pneumonia. OGG1 excises 8-oxoGua and generates an AP-site a substrate for APE1. APE1 binding leads to melting of the guanine duplex and stalls because of the non-canonical structure. Stalled APE1 increases transcription factor loading on the DNA via transient cooperative binding via conformational change of the helix. APE1, via its interacting domain, interacts with TFs (e.g., HIF1- $\alpha$, STAT3, and CBP/p300) to modulate their redox state and promote both their binding to cis elements and gene expression. (C) OGG1-dependent transcription initiated by estrogens and its nuclear receptor. Estrogen (17 $\beta$ estradiol; E2) binding to estrogen receptor alpha $(\mathrm{ER} \alpha)$ results in demethylation of histone H3 lysine 9 (H3K9me2) via lysine-specific histone demethylase (LSD1; a flavin-dependent amine oxidase). Histone demethylation leads to a focal superoxide anion, hydroxyl radical generation and induces site-specific oxidation of guanine to 8-oxoGua. The latter is recognized and excised by OGG1 and via its AP-lyase activity cleave into the DNA strand generating the AP-site. The strand gap is recognized by topoisomerase II beta (topo IIb), which results in DNA structural changes in the chromatin allowing efficient assembly of transcriptional machinery and gene expression. Such scenarios are relevant to acute lung injury and SARS-CoV-2 infection capacity $[138,139]$. Similarly, LSD1-dependent DNA oxidation and OGG1 recruitment was needed for gene expression driven by $\mathrm{TNF} \alpha$, retinoic acid, and androgen exposure of cells [140-142]. Abbreviations: AP-site, apurinic/apyrimidinic site; APE-1, apurinic/apyrimidinic endonuclease 1; FAD, flavin adenine dinucleotide; FADH2, reduced flavin adenine dinucleotide; LSD1, flavin-dependent amine oxidase 1, 3-OH, 3-terminal hydroxyl; $5^{\prime}$-dRP, 5-terminal deoxyribose-phosphate.

Inhibitors of OGG1 and 8-Oxogua Interactions in the DNA Helix Decreases Expression of Inflammatory Mediators and Inflammation

Studies described in Section 6, and references therein, show that OGG1, with or without 8-oxoGua excision, can regulate inflammatory responses (Figure 3A). Therefore, prevention of OGG1 interactions with genomic 8-oxoGua by inhibitors offer novel therapeutic opportunities (Figure 3). Pioneering studies by Dr. Lloyd's laboratory have identified a family of hydrazide/acyl hydrazone inhibitor chemotypes (e.g., 3,4-dichloro-benzo[b]thiophene- 
2-carboxylic acid hydrazide), also known as O8, which inhibit OGG1-mediated catalysis at sub micromolar concentrations [143]. It allows OGG1 substrate interaction, but inhibits glycosylase activity, and thus stabilizes the OGG1-8-oxoGua complex.

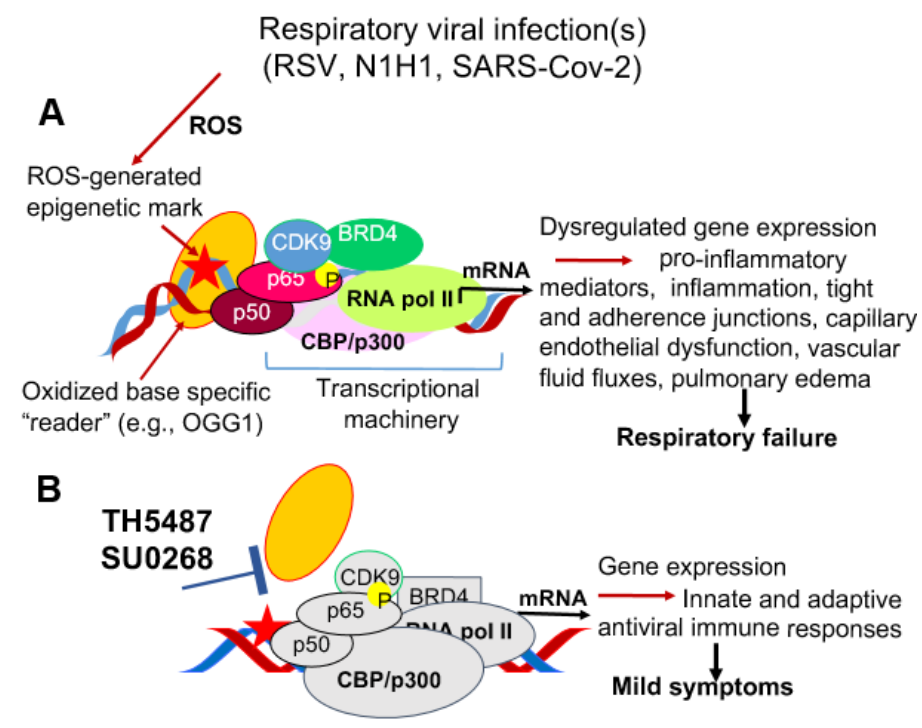

Figure 3. Proposed depiction of endothelial dysfunction by ROS in respiratory virus-infected airways and potential therapeutic intervention. (A) Oxidative modification to the heterocyclic DNA base guanine(s) in gene regulatory sequences is considered an epigenetic mark that is recognized by the "reader" OGG1, leading assembly of transcriptional complex and dysregulated gene expression. Consequences are pulmonary edema, congestion, respiratory failure in patients with risk factor(s). (B) Inhibition of OGG1' interaction with epigenetic mark decreases extent of inflammation and manifestation of endothelial dysfunction. TH5487, and SUO268, OGG1 specific inhibitors; BRD4, bromodomain-containing protein 4; CDK9, cyclin-dependent kinase 9; p50-p65, nuclear factor kappa $\mathrm{B} ; \mathrm{CBP} / \mathrm{p} 300, \mathrm{RNA}$ pol II, RNA polymerase II.

Another research group developed a chemically different compound, SU0268 that was shown to be selective for inhibiting OGG1 over other DNA base excision repair enzymes, and had dispensable toxicity in cultured human cell lines. The addition of SU0268 to cultured cells, inhibited OGG1 substrate binding and increased in intrahelical 8-oxoGua level [144-146]. SU0268 administration to experimental animals attenuate robust airway inflammation and increased survival rates after Pseudomonas aeruginosa infection. Remarkably, inhibition of OGG1 substrate binding increased type I IFN expression, which decreased bacterial load and disease progression [146].

Because OGG1-deficient mice are resistant to acute and systemic pulmonary inflammation, it was hypothesized that OGG1 inhibition may represent a strategy for the prevention and treatment. Therefore, a highly potent and selective small molecule inhibitor of OGG1, TH5487 [4-(4-Bromo-2-oxo-3H-benzimidazol-1-yl)-N-(4-iodophenyl) piperidine1-carboxamide)] was developed [147]. The compound shows excellent membrane permeability and low levels of cytotoxicity in cultured cells and animals [147]. TH5487 precludes OGG1 binding to substrate-containing DNA in vitro and to genomic 8-oxoGua at nanomolar concentrations. Its administration to experimental animals challenged with bacterial lipopolysaccharides or TNF $\alpha$ decreases DNA occupancy of nuclear factor $\mathrm{kB}$ and suppress pro-inflammatory gene expression, airway endothelial permeability and inflammation $[147,148]$.

Importantly, TH5487 is tolerated well when added repeatedly to experimental animals infected intrapulmonarily with RSV. TH5484 attenuated RSV-induced expression from inflammatory genes, accumulation of inflammatory cells and decreased endothelial permeability. Compared to untreated RSV-infected animals, histopathological analysis of Hematoxylin and Eosin (H\&E) stained lung sections showed that inhibition of OGG1' 
substrate binding decreased the density of perivascular inflammatory infiltrates (e.g., neutrophils, macrophages) and the number of inflammatory cells in alveoli, and their perivascular accumulation. Treatment with TH5487 of RSV-infectedor SARS-CoV-2infected human small airway epithelial cells (a relevant cell type to bronchiolitis) significantly decreased expression of over thirty pro-inflammatory genes including TNF, CCL20, IL6, CCL5 and CXCL10 at RNA and protein levels (GSE157630).

Overall, the small molecules TH5487 and SU0268 are first-in-class inhibitors of gene expression that depends on oxidative stress-generated epigenetic marks. They therefore may have clinical utility to lessen severe/chronic airway inflammation induced by respiratory viral infections. Of note is that the OGG1 inhibitor is used as a tool, and the possibility of using it in humans is speculative at this time.

\section{Conclusions}

Viral respiratory infections that cause endothelial dysfunction can have life-threatening consequences due to the central role of pulmonary endothelial cells in tissue homeostasis. Expression and secretion of soluble mediators and adhesion molecules generate inflammatory signaling cascades that shape the microenvironment of endothelial cells and compromises vascular integrity. Oxidative stress is increased in cells during inflammation and has a central function in the mechanism of activation of inflammatory gene expression. Although prevention of severe pathological sequelae is difficult, it is nevertheless feasible by interfering with the molecular mechanisms that induce inflammatory gene expression by viral infection. This type of molecular interference is already under clinical development. Finally, the recently developed small molecule OGG1 inhibitors, with nanomolar binding affinity, has provided a useful tool to test the role of oxidative stress-induced DNA base lesion(s) and OGG1 interactions, as rate limiting steps in violent cytokine storm and inflammation after viral and bacterial infection of the lungs.

Author Contributions: S.V. and I.B. designed and wrote the manuscript, L.P., Y.X., X.Z. and K.W. performed cell culture and animal experiments and did artwork. All authors have read and agreed to the published version of the manuscript.

Funding: This work was funded by the NIH National Institute of Allergy and Infectious Diseases NIAID/AI062885 (I.B.). National Natural Science Foundation of China/31900424 (L.P.).

Institutional Review Board Statement: Animal experiments were carried out in accordance with Guide for the Care and Use of Laboratory Animals of the National Institutes of Health. The protocol was approved by the Institutional Animal Care and Use Committee of the University of Texas Medical Branch at Galveston (Protocol \#: 0807044D).

Informed Consent Statement: Not applicable.

Data Availability Statement: Cytokine and chemokinedata is deposited at National Center for Biotechnology Information, Gene Expression Omnibus (GEO) number: GSE157630.

Acknowledgments: Authors thank Linsey Yeager and Sherry Haller for scientific advice and editing the manuscript.

Conflicts of Interest: The authors declare no conflict of interest.

\section{References}

1. Pober, J.S.; Sessa, W. Evolving functions of endothelial cells in inflammation. Nat. Rev. Immunol. 2007, 7, 803-815. [CrossRef]

2. Herrero, R.; Sanchez, G.; Lorente, J.A. New insights into the mechanisms of pulmonary edema in acute lung injury. Ann. Transl. Med. 2018, 6, 32. [CrossRef]

3. Aird, W.C. Phenotypic Heterogeneity of the Endothelium. Circ. Res. 2007, 100, 174-190. [CrossRef] [PubMed]

4. Fosse, J.H.; Haraldsen, G.; Falk, K.; Edelmann, R. Endothelial Cells in Emerging Viral Infections. Front. Cardiovasc. Med. 2021, 8, 619690. [CrossRef]

5. Handel, A.; Yates, A.; Pilyugin, S.S.; Antia, R. Sharing the burden: Antigen transport and firebreaks in immune responses. J. R. Soc. Interface 2008, 6, 447-454. [CrossRef] [PubMed] 
6. Spray, D.C.; Hanstein, R.; Lopez-Quintero, S.V.; Jr, R.F.S.; Suadicani, S.O.; Thi, M.M. Gap junctions and Bystander effects: Good Samaritans and executioners. Wiley Interdiscip. Rev. Membr. Transp. Signal. 2012, 2, 1-15. [CrossRef] [PubMed]

7. Lavigne, G.M.; Russell, H.; Sherry, B.; Ke, R. Autocrine and paracrine interferon signalling as 'ring vaccination' and 'contact tracing' strategies to suppress virus infection in a host. Proc. R. Soc. B: Boil. Sci. 2021, 288, 20203002. [CrossRef] [PubMed]

8. Xu, Q.-B. Endothelial progenitor cells in angiogenesis. Sheng li xue bao: [Acta Physiol. Sin.] 2005, 57, 1-6.

9. Schleimer, R.P.; A Sterbinsky, S.; Kaiser, J.; A Bickel, C.; A Klunk, D.; Tomioka, K.; Newman, W.; Luscinskas, F.W.; A Gimbrone, M.; McIntyre, B.W. IL-4 induces adherence of human eosinophils and basophils but not neutrophils to endothelium. Association with expression of VCAM-1. J. Immunol. 1992, 148.

10. Montefort, S.; Feather, I.H.; Wilson, S.J.; Haskard, D.O.; Lee, T.H.; Holgate, S.T.; Howarth, P.H. The Expression of LeukocyteEndothelial Adhesion Molecules Is Increased in Perennial Allergic Rhinitis. Am. J. Respir. Cell Mol. Biol. 1992, 7, $393-398$. [CrossRef]

11. Schleimer, R.P.; Bochner, B.S. Endothelial leukocyte adhesion molecule-1 and intercellular adhesion molecule-1 mediate the adhesion of eosinophils to endothelial cells in vitro and are expressed by endothelium in allergic cutaneous inflammation in vivo. J. Immunol. 1991, 147, 380-381.

12. Kyan-Aung, U.; O Haskard, D.; Poston, R.N.; Thornhill, M.; Lee, T. Endothelial leukocyte adhesion molecule-1 and intercellular adhesion molecule- 1 mediate the adhesion of eosinophils to endothelial cells in vitro and are expressed by endothelium in allergic cutaneous inflammation in vivo. J. Immunol. 1991, 146, 521-528.

13. Stefanović, L.; Bogić, M.; Balaban, J.; Mitrović, O.; Stosović, R.; Andrejević, S. [The role of endothelial cells in allergic inflammation reactions]. Srp. Arh. za Celok. Lek. 1998, 126.

14. Green, C.E.; Turner, A.M. The role of the endothelium in asthma and chronic obstructive pulmonary disease (COPD). Respir. Res. 2017, 18, 1-14. [CrossRef] [PubMed]

15. Middleton, J.; Americh, L.; Gayon, R.; Julien, D.; Mansat, M.; Mansat, P.; Anract, P.; Cantagrel, A.; Cattan, P.; Reimund, J.-M.; et al. A comparative study of endothelial cell markers expressed in chronically inflamed human tissues: MECA-79, Duffy antigen receptor for chemokines, von Willebrand factor, CD31, CD34, CD105 and CD146. J. Pathol. 2005, 206, 260-268. [CrossRef]

16. Zola, H.; Swart, B.; Nicholson, I.; Aasted, B.; Bensussan, A.; Boumsell, L.; Buckley, C.; Clark, G.; Drbal, K.; Engel, P.; et al. CD molecules 2005: Human cell differentiation molecules. Blood 2005, 106, 3123-3126. [CrossRef] [PubMed]

17. Mostmans, Y.; De Smedt, K.; Richert, B.; Komi, D.E.A.; Maurer, M.; Michel, O. Markers for the involvement of endothelial cells and the coagulation system in chronic urticaria: A systematic review. Allergy 2021, 76, 2998-3016. [CrossRef]

18. Niethamer, T.K.; Stabler, C.T.; Leach, J.; A Zepp, J.; Morley, M.P.; Babu, A.; Zhou, S.; E Morrisey, E. Defining the role of pulmonary endothelial cell heterogeneity in the response to acute lung injury. eLife 2020, 9. [CrossRef] [PubMed]

19. Saxena, A.; Walters, M.S.; Shieh, J.-H.; Shen, L.-B.; Gomi, K.; Downey, R.J.; Crystal, R.G.; Moore, M.A.S. Extracellular vesicles from human airway basal cells respond to cigarette smoke extract and affect vascular endothelial cells. Sci. Rep. 2021, 11, 1-12. [CrossRef]

20. Karnati, S.; Seimetz, M.; Kleefeldt, F.; Sonawane, A.; Madhusudhan, T.; Bachhuka, A.; Kosanovic, D.; Weissmann, N.; Krüger, K.; Ergün, S. Chronic Obstructive Pulmonary Disease and the Cardiovascular System: Vascular Repair and Regeneration as a Therapeutic Target. Front. Cardiovasc. Med. 2021, 8. [CrossRef] [PubMed]

21. Sukriti, S.; Tauseef, M.; Yazbeck, P.; Mehta, D. Mechanisms Regulating Endothelial Permeability. Pulm. Circ. $2014,4,535-551$. [CrossRef] [PubMed]

22. Asosingh, K.; Weiss, K.; Queisser, K.; Wanner, N.; Yin, M.; Aronica, M.; Erzurum, S. Endothelial cells in the innate response to allergens and initiation of atopic asthma. J. Clin. Investig. 2018, 128, 3116-3128. [CrossRef]

23. Shoda, T.; Futamura, K.; Orihara, K.; Emi-Sugie, M.; Saito, H.; Matsumoto, K.; Matsuda, A. Recent advances in understanding the roles of vascular endothelial cells in allergic inflammation. Allergol. Int. 2015, 65, 21-29. [CrossRef]

24. Singh, D.; McCann, K.L.; Imani, F. MAPK and heat shock protein 27 activation are associated with respiratory syncytial virus induction of human bronchial epithelial monolayer disruption. Am. J. Physiol. Cell. Mol. Physiol. 2007, 293, L436-L445. [CrossRef] [PubMed]

25. Chatterjee, A.; Mavunda, K.; Krilov, L.R. Current State of Respiratory Syncytial Virus Disease and Management. Infect. Dis. Ther. 2021, 1-12. [CrossRef]

26. Martin, G.S.; Brigham, K.L. Fluid Flux and Clearance in Acute Lung Injury. Compr. Physiol. 2012, 2, 2471-2480. [CrossRef] [PubMed]

27. Tian, B.; Zhang, Y.; Luxon, B.A.; Garofalo, R.P.; Casola, A.; Sinha, M.; Brasier, A.R. Identification of NF-кB-Dependent Gene Networks in Respiratory Syncytial Virus-Infected Cells. J. Virol. 2002, 76, 6800-6814. [CrossRef]

28. Ganter, M.T.; Roux, J.; Miyazawa, B.; Howard, M.; Frank, J.A.; Su, G.; Sheppard, D.; Violette, S.M.; Weinreb, P.; Horan, G.S.; et al. Interleukin-1 $\beta$ Causes Acute Lung Injury via $\alpha v \beta 5$ and $\alpha v \beta 6$ Integrin-Dependent Mechanisms. Circ. Res. 2008, 102, 804-812. [CrossRef]

29. Pugin, J.; Ricou, B.; Steinberg, K.P.; Suter, P.M.; Martin, T.R. Proinflammatory activity in bronchoalveolar lavage fluids from patients with ARDS, a prominent role for interleukin-1. Am. J. Respir. Crit. Care Med. 1996, 153, 1850-1856. [CrossRef]

30. Petrache, I.; Birukova, A.; Ramirez, S.I.; Garcia, J.G.N.; Verin, A.D. The Role of the Microtubules in Tumor Necrosis Factor- $\alpha-$ Induced Endothelial Cell Permeability. Am. J. Respir. Cell Mol. Biol. 2003, 28, 574-581. [CrossRef] 
31. Bruewer, M.; Luegering, A.; Kucharzik, T.; Parkos, C.A.; Madara, J.L.; Hopkins, A.; Nusrat, A. Proinflammatory Cytokines Disrupt Epithelial Barrier Function by Apoptosis-Independent Mechanisms. J. Immunol. 2003, 171, 6164-6172. [CrossRef]

32. Mazzon, E.; Cuzzocrea, S. Role of TNF- $\alpha$ in lung tight junction alteration in mouse model of acute lung inflammation. Respir. Res. 2007, 8, 75. [CrossRef]

33. Hermanns, M.I.; Kasper, J.; Dubruel, P.; Pohl, C.; Uboldi, C.; Vermeersch, V.; Fuchs, S.; Unger, R.E.; Kirkpatrick, C.J. An impaired alveolar-capillary barrier in vitro: Effect of proinflammatory cytokines and consequences on nanocarrier interaction. J. $R$. Soc. Interface 2009, 7, S41-S54. [CrossRef] [PubMed]

34. Li, Q.; Zhang, Q.; Wang, M.; Zhao, S.; Ma, J.; Luo, N.; Li, N.; Li, Y.; Xu, G.; Li, J. Interferon- $\gamma$ and tumor necrosis factor- $\alpha$ disrupt epithelial barrier function by altering lipid composition in membrane microdomains of tight junction. Clin. Immunol. 2008, 126, 67-80. [CrossRef]

35. Al-Sadi, R. Mechanism of cytokine modulation of epithelial tight junction barrier. Front. Biosci. 2009, 14, 2765-2778. [CrossRef] [PubMed]

36. Koss, M.; Pfeiffer, G.R.; Wang, Y.; Thomas, S.T.; Yerukhimovich, M.; Gaarde, W.A.; Doerschuk, C.M.; Wang, Q. Ezrin/Radixin/Moesin Proteins Are Phosphorylated by TNF- $\alpha$ and Modulate Permeability Increases in Human Pulmonary Microvascular Endothelial Cells. J. Immunol. 2006, 176, 1218-1227. [CrossRef]

37. McKenzie, J.A.; Ridley, A.J. Roles of Rho/ROCK and MLCK in TNF- $\alpha$-induced changes in endothelial morphology and permeability. J. Cell. Physiol. 2007, 213, 221-228. [CrossRef] [PubMed]

38. Wang, S.; Le, T.Q.; Kurihara, N.; Chida, J.; Cisse, Y.; Yano, M.; Kido, H. Influenza Virus-Cytokine-Protease Cycle in the Pathogenesis of Vascular Hyperpermeability in Severe Influenza. J. Infect. Dis. 2010, 202, 991-1001. [CrossRef]

39. Ahdieh, M.; Vandenbos, T.; Youakim, A. Lung epithelial barrier function and wound healing are decreased by IL-4 and IL-13 and enhanced by IFN- $\gamma$. Am. J. Physiol. Physiol. 2001, 281, C2029-C2038. [CrossRef]

40. Dawre, S.; Maru, S. Human respiratory viral infections: Current status and future prospects of nanotechnology-based approaches for prophylaxis and treatment. Life Sci. 2021, 278, 119561. [CrossRef]

41. Chatzis, O.; Darbre, S.; Pasquier, J.; Meylan, P.; Manuel, O.; Aubert, J.D.; Beck-Popovic, M.; Masouridi-Levrat, S.; Ansari, M.; Kaiser, L.; et al. Burden of severe RSV disease among immunocompromised children and adults: A 10 year retrospective study. BMC Infect. Dis. 2018, 18, 1-9. [CrossRef]

42. Rima, B.; Collins, P.; Easton, A.; Fouchier, R.; Kurath, G.; Lamb, R.A.; Lee, B.; Maisner, A.; Rota, P.; Wang, L.; et al. ICTV Virus Taxonomy Profile: Pneumoviridae. J. Gen. Virol. 2017, 98, 2912-2913. [CrossRef]

43. Brasier, A.R. RSV Reprograms the CDK9•BRD4 Chromatin Remodeling Complex to Couple Innate Inflammation to Airway Remodeling. Viruses 2020, 12, 472. [CrossRef]

44. Welliver, T.P.; Garofalo, R.P.; Hosakote, Y.; Hintz, K.H.; Avendano, L.; Sanchez, K.; Velozo, L.; Jafri, H.; Chavez-Bueno, S.; Ogra, P.L.; et al. Severe Human Lower Respiratory Tract Illness Caused by Respiratory Syncytial Virus and Influenza Virus Is Characterized by the Absence of Pulmonary Cytotoxic Lymphocyte Responses. J. Infect. Dis. 2007, 195, 1126-1136. [CrossRef] [PubMed]

45. Bennett, B.L.; Garofalo, R.P.; Cron, S.G.; Hosakote, Y.M.; Atmar, R.L.; Macias, C.G.; Piedra, P.A. Immunopathogenesis of Respiratory Syncytial Virus Bronchiolitis. J. Infect. Dis. 2007, 195, 1532-1540. [CrossRef] [PubMed]

46. Zlateva, K.T.; Van Ranst, M. DETECTION OF SUBGROUP B RESPIRATORY SYNCYTIAL VIRUS IN THE CEREBROSPINAL FLUID OF A PATIENT WITH RESPIRATORY SYNCYTIAL VIRUS PNEUMONIA. Pediatr. Infect. Dis. J. 2004, 23, 1065-1066. [CrossRef]

47. E Bowles, N.; Ni, J.; Kearney, D.L.; Pauschinger, M.; Schultheiss, H.-P.; McCarthy, R.; Hare, J.; Bricker, J.; Bowles, K.R.; A Towbin, J. Detection of viruses in myocardial tissues by polymerase chain reaction: Evidence of adenovirus as a common cause of myocarditis in children and adults. J. Am. Coll. Cardiol. 2003, 42, 466-472. [CrossRef]

48. Nadal, D.; Wunderli, W.; Meurmann, O.; Briner, J.; Hirsig, J. Isolation of Respiratory Syncytial Virus from Liver Tissue and Extrahepatic Biliary Atresia Material. Scand. J. Infect. Dis. 1990, 22, 91-93. [CrossRef] [PubMed]

49. Gkentzi, D.; Dimitriou, G.; Karatza, A. Non-pulmonary manifestations of respiratory syncytial virus infection. J. Thorac. Dis. 2018, 10, S3815-S3818. [CrossRef] [PubMed]

50. Eiland, L.S. Respiratory Syncytial Virus: Diagnosis, Treatment and Prevention. J. Pediatr. Pharmacol. Ther. 2009, 14, 75-85. [CrossRef] [PubMed]

51. Ralston, S.L.; Lieberthal, A.S.; Meissner, H.C.; Alverson, B.K.; Baley, J.E.; Gadomski, A.M.; Johnson, D.W.; Light, M.J.; Maraqa, N.F.; Mendonca, E.A.; et al. Clinical Practice Guideline: The Diagnosis, Management, and Prevention of Bronchiolitis. Pediatrics 2014, 134, e1474-e1502. [CrossRef] [PubMed]

52. Barr, R.; Green, C.A.; Sande, C.J.; Drysdale, S.B. Respiratory syncytial virus: Diagnosis, prevention and management. Ther. Adv. Infect. Dis. 2019, 6. [CrossRef]

53. Beijnen, E.M.S.; Van Haren, S.D. Vaccine-Induced CD8+ T Cell Responses in Children: A Review of Age-Specific Molecular Determinants Contributing to Antigen Cross-Presentation. Front. Immunol. 2020, 11, 607977. [CrossRef] [PubMed]

54. Biagi, C.; Dondi, A.; Scarpini, S.; Rocca, A.; Vandini, S.; Poletti, G.; Lanari, M. Current State and Challenges in Developing Respiratory Syncytial Virus Vaccines. Vaccines 2020, 8, 672. [CrossRef]

55. Walsh, E.E. Respiratory Syncytial Virus Infection. Clin. Chest Med. 2016, 38, 29-36. [CrossRef] [PubMed] 
56. E Johnson, J.; A Gonzales, R.; Olson, S.J.; Wright, P.F.; Graham, B.S. The histopathology of fatal untreated human respiratory syncytial virus infection. Mod. Pathol. 2006, 20, 108-119. [CrossRef] [PubMed]

57. Norlander, A.E.; Peebles, R.S., Jr. Innate Type 2 Responses to Respiratory Syncytial Virus Infection. Viruses 2020, $12,521$. [CrossRef]

58. Chang, C.-H.; Huang, Y.; Anderson, R. Activation of vascular endothelial cells by IL-1 $\alpha$ released by epithelial cells infected with respiratory syncytial virus. Cell. Immunol. 2003, 221, 37-41. [CrossRef]

59. Haeberle, H.A.; Kuziel, W.A.; Dieterich, H.-J.; Casola, A.; Gatalica, Z.; Garofalo, R.P. Inducible Expression of Inflammatory Chemokines in Respiratory Syncytial Virus-Infected Mice: Role of MIP-1 $\alpha$ in Lung Pathology. J. Virol. 2001, 75, 878-890. [CrossRef]

60. Arnold, R.; Nig, W.K. Respiratory Syncytial Virus Infection of Human Lung Endothelial Cells Enhances Selectively Intercellular Adhesion Molecule-1 Expression. J. Immunol. 2005, 174, 7359-7367. [CrossRef]

61. Juliana, A.; Zonneveld, R.; Plötz, F.B.; van Meurs, M.; Wilschut, J. Neutrophil-endothelial interactions in respiratory syncytial virus bronchiolitis: An understudied aspect with a potential for prediction of severity of disease. J. Clin. Virol. 2019, 123, 104258. [CrossRef]

62. Johansson, C.; Kirsebom, F.C.M. Neutrophils in respiratory viral infections. Mucosal Immunol. 2021, 1-13. [CrossRef]

63. Jamaluddin, M.; Tian, B.; Boldogh, I.; Garofalo, R.P.; Brasier, A.R. Respiratory Syncytial Virus Infection Induces a Reactive Oxygen Species-MSK1-Phospho-Ser-276 RelA Pathway Required for Cytokine Expression. J. Virol. 2009, 83, 10605-10615. [CrossRef]

64. Brasier, A.R.; Boldogh, I. Targeting inducible epigenetic reprogramming pathways in chronic airway remodeling. Drugs Context 2019, 8, 1-10. [CrossRef]

65. Muramoto, Y.; Takada, A.; Fujii, K.; Noda, T.; Iwatsuki-Horimoto, K.; Watanabe, S.; Horimoto, T.; Kida, H.; Kawaoka, Y. Hierarchy among Viral RNA (vRNA) Segments in Their Role in vRNA Incorporation into Influenza A Virions. J. Virol. 2006, 80, 2318-2325. [CrossRef]

66. Zhuang, Q.; Wang, S.; Liu, S.; Hou, G.; Li, J.; Jiang, W.; Wang, K.; Peng, C.; Liu, D.; Guo, A.; et al. Diversity and distribution of type A influenza viruses: An updated panorama analysis based on protein sequences. Virol. J. 2019, 16, 1-38. [CrossRef] [PubMed]

67. Coronaviridae Study Group of the International Committee on Taxonomy of Viruses The species Severe acute respiratory syndrome-related coronavirus: Classifying 2019-nCoV and naming it SARS-CoV-2. Nat. Microbiol. 2020, 5, 536-544. [CrossRef] [PubMed]

68. Moore, K.A.; Ostrowsky, J.T.; Kraigsley, A.M.; Mehr, A.J.; Bresee, J.S.; Friede, M.H.; Gellin, B.G.; Golding, J.P.; Hart, P.J.; Moen, A.; et al. A Research and Development (R\&D) roadmap for influenza vaccines: Looking toward the future. Vaccine 2021, 39, 6573-6584. [CrossRef] [PubMed]

69. Poland, G.A.; Ovsyannikova, I.G.; Kennedy, R.B. The need for broadly protective COVID-19 vaccines: Beyond S-only approaches. Vaccine 2021, 39, 4239-4241. [CrossRef]

70. Ru, Y.-X.; Li, Y.-C.; Zhao, Y.; Zhao, S.-X.; Yang, J.-P.; Zhang, H.-M.; Pang, T.-X. Multiple Organ Invasion by Viruses: Pathological Characteristics in Three Fatal Cases of the 2009 Pandemic Influenza A/H1N1. Ultrastruct. Pathol. 2011, 35, 155-161. [CrossRef] [PubMed]

71. Visseren, F.L.J.; Verkerk, M.S.A.; Van Der Bruggen, T.; Marx, J.J.M.; Van Asbeck, B.S.; Diepersloot, R.J.A. Iron chelation and hydroxyl radical scavenging reduce the inflammatory response of endothelial cells after infection with Chlamydia pneumoniae or influenza A. Eur. J. Clin. Investig. 2002, 32, 84-90. [CrossRef]

72. Ackermann, M.; Verleden, S.; Kuehnel, M.; Haverich, A.; Welte, T.; Laenger, F.; Vanstapel, A.; Werlein, C.; Stark, H.; Tzankov, A.; et al. Pulmonary Vascular Endothelialitis, Thrombosis, and Angiogenesis in Covid-19. New Engl. J. Med. 2020, 383, 120-128. [CrossRef] [PubMed]

73. Choreño-Parra, J.A.; Jiménez-Álvarez, L.A.; Ramírez-Martínez, G.; Cruz-Lagunas, A.; Thapa, M.; Fernández-López, L.A.; CarnallaCortés, M.; Choreño-Parra, E.M.; Mena-Hernández, L.; Sandoval-Vega, M.; et al. Expression of Surfactant Protein D Distinguishes Severe Pandemic Influenza A(H1N1) from Coronavirus Disease 2019. J. Infect. Dis. 2021. [CrossRef] [PubMed]

74. de Paula, C.B.V.; De Azevedo, M.L.V.; Nagashima, S.; Martins, A.P.C.; Malaquias, M.A.S.; Miggiolaro, A.F.R.D.S.; Júnior, J.D.S.M.; Avelino, G.; Carmo, L.A.P.D.; Carstens, L.B.; et al. IL-4/IL-13 remodeling pathway of COVID-19 lung injury. Sci. Rep. 2020, 10, 1-8. [CrossRef]

75. Poor, H.D.; Ventetuolo, C.E.; Tolbert, T.; Chun, G.; Serrao, G.; Zeidman, A.; Dangayach, N.S.; Olin, J.; Kohli-Seth, R.; Powell, C.A. COVID-19 critical illness pathophysiology driven by diffuse pulmonary thrombi and pulmonary endothelial dysfunction responsive to thrombolysis. Clin. Transl. Med. 2020, 10. [CrossRef]

76. Oxford, A.E.; Halla, F.; Robertson, E.B.; Morrison, B.E. Endothelial Cell Contributions to COVID-19. Pathogens 2020, 9, 785. [CrossRef]

77. Bao, W.; Zhang, X.; Jin, Y.; Hao, H.; Yang, F.; Yin, D.; Chen, X.; Xue, Y.; Han, L.; Zhang, M. Factors Associated with the Expression of ACE2 in Human Lung Tissue: Pathological Evidence from Patients with Normal FEV1 and FEV1/FVC. J. Inflamm. Res. 2021, 14, 1677-1687. [CrossRef]

78. Conde, J.N.; Schutt, W.R.; Gorbunova, E.E.; Mackow, E.R. Recombinant ACE2 Expression Is Required for SARS-CoV-2 To Infect Primary Human Endothelial Cells and Induce Inflammatory and Procoagulative Responses. mBio 2020, 11. [CrossRef] 
79. Vasquez-Bonilla, W.O.; Orozco, R.; Argueta, V.; Sierra, M.; Zambrano, L.I.; Muñoz-Lara, F.; López-Molina, D.S.; Arteaga-Livias, K.; Grimes, Z.; Bryce, C.; et al. A review of the main histopathological findings in coronavirus disease 2019. Hum. Pathol. 2020, 105, 74-83. [CrossRef] [PubMed]

80. Rotulo, G.A.; Casalini, E.; Brisca, G.; Piccotti, E.; Castagnola, E. Unexpected peak of bronchiolitis requiring oxygen therapy in February 2020: Could an undetected SARS-CoV2-RSV co-infection be the cause? Pediatr. Pulmonol. 2021, 56, 1803-1805. [CrossRef] [PubMed]

81. Monteil, V.; Kwon, H.; Prado, P.; Hagelkrüys, A.; Wimmer, R.A.; Stahl, M.; Leopoldi, A.; Garreta, E.; Del Pozo, C.H.; Prosper, F.; et al. Inhibition of SARS-CoV-2 Infections in Engineered Human Tissues Using Clinical-Grade Soluble Human ACE2. Cell 2020, 181, 905-913.e7. [CrossRef]

82. Chernyak, B.V.; Popova, E.N.; Prikhodko, A.S.; Grebenchikov, O.A.; Zinovkina, L.A.; Zinovkin, R.A. COVID-19 and Oxidative Stress. Biochem. (Moscow) 2020, 85, 1543-1553. [CrossRef] [PubMed]

83. Sodhi, C.P.; Wohlford-Lenane, C.; Yamaguchi, Y.; Prindle, T.; Fulton, W.B.; Wang, S.; McCray, P.B., Jr.; Chappell, M.; Hackam, D.J.; Jia, H. Attenuation of pulmonary ACE2 activity impairs inactivation of des-Arg9 bradykinin/BKB1R axis and facilitates LPS-induced neutrophil infiltration. Am. J. Physiol. Cell. Mol. Physiol. 2018, 314, L17-L31. [CrossRef] [PubMed]

84. Song, X.; Hu, W.; Yu, H.; Zhao, L.; Zhao, Y.; Zhao, X.; Xue, H.; Zhao, Y. Little to no expression of angiotensin-converting enzyme-2 on most human peripheral blood immune cells but highly expressed on tissue macrophages. Cytom. Part A 2020. [CrossRef]

85. Hamming, I.; Timens, W.; Bulthuis, M.; Lely, A.; Navis, G.; van Goor, H. Tissue distribution of ACE2 protein, the functional receptor for SARS coronavirus. A first step in understanding SARS pathogenesis. J. Pathol. 2004, 203, 631-637. [CrossRef] [PubMed]

86. Hikmet, F.; Méar, L.; Edvinsson, Å.; Micke, P.; Uhlén, M.; Lindskog, C. The protein expression profile of ACE2 in human tissues. Mol. Syst. Biol. 2020, 16, e9610. [CrossRef]

87. Ziegler, C.G.; Allon, S.J.; Nyquist, S.K.; Mbano, I.M.; Miao, V.N.; Tzouanas, C.N.; Cao, Y.; Yousif, A.; Bals, J.; Hauser, B.; et al. SARS-CoV-2 Receptor ACE2 Is an Interferon-Stimulated Gene in Human Airway Epithelial Cells and Is Detected in Specific Cell Subsets across Tissues. Cell 2020, 181, 1016-1035.e19. [CrossRef]

88. Zou, X.; Chen, K.; Zou, J.; Han, P.; Hao, J.; Han, Z. Single-cell RNA-seq data analysis on the receptor ACE2 expression reveals the potential risk of different human organs vulnerable to 2019-nCoV infection. Front. Med. 2020, 14, 185-192. [CrossRef]

89. Guazzi, M.; Gomberg-Maitland, M.; Naeije, R. Impact of Pharmacologic Interventions-Treating Endothelial Dysfunction and Group 2 Pulmonary Hypertension. Prog. Cardiovasc. Dis. 2015, 57, 473-479. [CrossRef]

90. Daiber, A.; Chlopicki, S. Revisiting pharmacology of oxidative stress and endothelial dysfunction in cardiovascular disease: Evidence for redox-based therapies. Free. Radic. Biol. Med. 2020, 157, 15-37. [CrossRef]

91. Hosakote, Y.M.; Komaravelli, N.; Mautemps, N.; Liu, T.; Garofalo, R.P.; Casola, A. Antioxidant mimetics modulate oxidative stress and cellular signaling in airway epithelial cells infected with respiratory syncytial virus. Am. J. Physiol. Cell. Mol. Physiol. 2012, 303, L991-L1000. [CrossRef] [PubMed]

92. Hosakote, Y.M.; Jantzi, P.D.; Esham, D.L.; Spratt, H.; Kurosky, A.; Casola, A.; Garofalo, R.P. Viral-mediated Inhibition of Antioxidant Enzymes Contributes to the Pathogenesis of Severe Respiratory Syncytial Virus Bronchiolitis. Am. J. Respir. Crit. Care Med. 2011, 183, 1550-1560. [CrossRef] [PubMed]

93. Garofalo, R.P.; Kolli, D.; Casola, A. Respiratory Syncytial Virus Infection: Mechanisms of Redox Control and Novel Therapeutic Opportunities. Antioxidants Redox Signal. 2013, 18, 186-217. [CrossRef] [PubMed]

94. Chen, K.-K.; Minakuchi, M.; Wuputra, K.; Ku, C.-C.; Pan, J.-B.; Kuo, K.-K.; Lin, Y.-C.; Saito, S.; Lin, C.-S.; Yokoyama, K.K. Redox control in the pathophysiology of influenza virus infection. BMC Microbiol. 2020, 20, 1-22. [CrossRef]

95. Brand, J.V.D.; Haagmans, B.; van Riel, D.; Osterhaus, A.; Kuiken, T. The Pathology and Pathogenesis of Experimental Severe Acute Respiratory Syndrome and Influenza in Animal Models. J. Comp. Pathol. 2014, 151, 83-112. [CrossRef]

96. Heras, N.D.L.; Giménez, V.M.M.; Ferder, L.; Manucha, W.; Lahera, V. Implications of Oxidative Stress and Potential Role of Mitochondrial Dysfunction in COVID-19: Therapeutic Effects of Vitamin D. Antioxidants 2020, 9, 897. [CrossRef] [PubMed]

97. Chang, R.; Mamun, A.; Dominic, A.; Le, N.-T. SARS-CoV-2 Mediated Endothelial Dysfunction: The Potential Role of Chronic Oxidative Stress. Front. Physiol. 2021, 11, 605908. [CrossRef] [PubMed]

98. Panfoli, I. Potential role of endothelial cell surface ectopic redox complexes in COVID-19 disease pathogenesis. Clin. Med. 2020, 20, e146-e147. [CrossRef]

99. Komaravelli, N.; Kelley, J.P.; Garofalo, M.P.; Wu, H.; Casola, A.; Kolli, D. Role of dietary antioxidants in human metapneumovirus infection. Virus Res. 2015, 200, 19-23. [CrossRef]

100. Fernandes, I.G.; De Brito, C.A.; Dos Reis, V.M.S.; Sato, M.N.; Pereira, N.Z. SARS-CoV-2 and Other Respiratory Viruses: What Does Oxidative Stress Have to Do with It? Oxidative Med. Cell. Longev. 2020, 2020, 1-13. [CrossRef]

101. Komaravelli, N.; Ansar, M.; Garofalo, R.P.; Casola, A. Respiratory syncytial virus induces NRF2 degradation through a promyelocytic leukemia protein - ring finger protein 4 dependent pathway. Free. Radic. Biol. Med. 2017, 113, 494-504. [CrossRef] [PubMed]

102. Kesic, M.J.; Simmons, S.O.; Bauer, R.; Jaspers, I. Nrf2 expression modifies influenza A entry and replication in nasal epithelial cells. Free. Radic. Biol. Med. 2011, 51, 444-453. [CrossRef] [PubMed]

103. DeMaula, C.D.; Leutenegger, C.M.; Bonneau, K.R.; MacLachlan, N. The Role of Endothelial Cell-Derived Inflammatory and Vasoactive Mediators in the Pathogenesis of Bluetongue. Virology 2002, 296, 330-337. [CrossRef] [PubMed] 
104. Herseth, J.; Refsnes, M.; Låg, M.; Hetland, G.; Schwarze, P. IL-1 $\beta$ as a determinant in silica-induced cytokine responses in monocyte-endothelial cell co-cultures. Hum. Exp. Toxicol. 2008, 27, 387-399. [CrossRef]

105. Lakshminarayanan, V.; Beno, D.W.A.; Costa, R.H.; Roebuck, K.A. Differential Regulation of Interleukin-8 and Intercellular Adhesion Molecule-1 by H2O2 and Tumor Necrosis Factor- $\alpha$ in Endothelial and Epithelial Cells. J. Biol. Chem. 1997, 272, 32910-32918. [CrossRef] [PubMed]

106. Lambrou, G.I.; Hatziagapiou, K.; Vlahopoulos, S. Inflammation and tissue homeostasis: The NF-kB system in physiology and malignant progression. Mol. Biol. Rep. 2020, 47, 4047-4063. [CrossRef] [PubMed]

107. Vlahopoulos, S.; Boldogh, I.; Casola, A.; Brasier, A.R. Nuclear factor-kappaB-dependent induction of interleukin-8 gene expression by tumor necrosis factor alpha: Evidence for an antioxidant sensitive activating pathway distinct from nuclear translocation. Blood 1999, 94, 1878-1889. [CrossRef] [PubMed]

108. Vlahopoulos, S.A.; Cen, O.; Hengen, N.; Agan, J.; Moschovi, M.; Critselis, E.; Adamaki, M.; Bacopoulou, F.; Copland, J.A.; Boldogh, I.; et al. Dynamic aberrant NF-kB spurs tumorigenesis: A new model encompassing the microenvironment. Cytokine Growth Factor Rev. 2015, 26, 389-403. [CrossRef]

109. E Hammond, M.; Lapointe, G.R.; Feucht, P.H.; Hilt, S.; A Gallegos, C.; A Gordon, C.; A Giedlin, M.; Mullenbach, G.; Tekamp-Olson, P. IL-8 induces neutrophil chemotaxis predominantly via type I IL-8 receptors. J. Immunol. 1995, 155, 1428-1433.

110. Winkler, E.S.; Bailey, A.L.; Kafai, N.M.; Nair, S.; McCune, B.T.; Yu, J.; Fox, J.M.; Chen, R.E.; Earnest, J.T.; Keeler, S.P.; et al. SARS-CoV-2 infection of human ACE2-transgenic mice causes severe lung inflammation and impaired function. Nat. Immunol. 2020, 21, 1327-1335. [CrossRef]

111. Ma, Q.; Li, R.; Pan, W.; Huang, W.; Liu, B.; Xie, Y.; Wang, Z.; Li, C.; Jiang, H.; Huang, J.; et al. Phillyrin (KD-1) exerts anti-viral and anti-inflammatory activities against novel coronavirus (SARS-CoV-2) and human coronavirus 229E (HCoV-229E) by suppressing the nuclear factor kappa B (NF-kB) signaling pathway. Phytomedicine 2020, 78, 153296. [CrossRef] [PubMed]

112. Lee, W.; Ahn, J.H.; Park, H.H.; Kim, H.N.; Kim, H.; Yoo, Y.; Shin, H.; Hong, K.S.; Jang, J.G.; Park, C.G.; et al. COVID-19-activated SREBP2 disturbs cholesterol biosynthesis and leads to cytokine storm. Signal Transduct. Target. Ther. 2020, 5, 1-11. [CrossRef] [PubMed]

113. Choudhary, S.; Boldogh, S.; Garofalo, R.; Jamaluddin, M.; Brasier, A.R. Respiratory Syncytial Virus Influences NF- $\kappa B-D e p e n d e n t$ Gene Expression through a Novel Pathway Involving MAP3K14/NIK Expression and Nuclear Complex Formation with NF- $\mathrm{B} 2$. J. Virol. 2005, 79, 8948-8959. [CrossRef]

114. Choudhary, S.; Boldogh, I.; Brasier, A. Inside-Out Signaling Pathways from Nuclear Reactive Oxygen Species Control Pulmonary Innate Immunity. J. Innate Immun. 2016, 8, 143-155. [CrossRef] [PubMed]

115. Schmolke, M.; Viemann, D.; Roth, J.; Ludwig, S. Essential Impact of NF-кB Signaling on the H5N1 Influenza A Virus-Induced Transcriptome. J. Immunol. 2009, 183, 5180-5189. [CrossRef]

116. Strengert, M.; Jennings, R.; Davanture, S.; Hayes, P.; Gabriel, G.; Knaus, U.G. Mucosal Reactive Oxygen Species Are Required for Antiviral Response: Role of Duox in Influenza A Virus Infection. Antioxidants Redox Signal. 2014, 20, 2695-2709. [CrossRef] [PubMed]

117. Nasi, A.; McArdle, S.; Gaudernack, G.; Westman, G.; Melief, C.; Rockberg, J.; Arens, R.; Kouretas, D.; Sjölin, J.; Mangsbo, S. Reactive oxygen species as an initiator of toxic innate immune responses in retort to SARS-CoV-2 in an ageing population, consider $\mathrm{N}$-acetylcysteine as early therapeutic intervention. Toxicol. Rep. 2020, 7, 768-771. [CrossRef]

118. Pasini, A.F.; Stranieri, C.; Cominacini, L.; Mozzini, C. Potential Role of Antioxidant and Anti-Inflammatory Therapies to Prevent Severe SARS-Cov-2 Complications. Antioxidants 2021, 10, 272. [CrossRef]

119. Ansar, M.; Ivanciuc, T.; Garofalo, R.P.; Casola, A. Increased Lung Catalase Activity Confers Protection Against Experimental RSV Infection. Sci. Rep. 2020, 10, 1-10. [CrossRef]

120. Morris, G.; Bortolasci, C.C.; Puri, B.K.; Olive, L.; Marx, W.; O'Neil, A.; Athan, E.; Carvalho, A.F.; Maes, M.; Walder, K.; et al. The pathophysiology of SARS-CoV-2: A suggested model and therapeutic approach. Life Sci. 2020, 258, 118166. [CrossRef]

121. Cecchini, R.; Cecchini, A.L. SARS-CoV-2 infection pathogenesis is related to oxidative stress as a response to aggression. Med. Hypotheses 2020, 143, 110102. [CrossRef]

122. Forcados, G.E.; Muhammad, A.; Oladipo, O.O.; Makama, S.; Meseko, C.A. Metabolic Implications of Oxidative Stress and Inflammatory Process in SARS-CoV-2 Pathogenesis: Therapeutic Potential of Natural Antioxidants. Front. Cell. Infect. Microbiol. 2021, 11, 654813. [CrossRef]

123. Dizdaroglu, M.; Jaruga, P.; Birincioglu, M.; Rodriguez, H. Free radical-induced damage to DNA: Mechanisms and measurement1,2. Free Radic. Biol. Med. 2002, 32, 1102-1115. [CrossRef]

124. Mitra, S.; Hazra, T.K.; Roy, R.; Ikeda, S.; Biswas, T.; Lock, J.; Boldogh, I.; Izumi, T. Complexities of DNA base excision repair in mammalian cells. Mol. Cells 1997, 7, 305-312.

125. Izumi, T.; Schein, C.H.; Oezguen, N.; Feng, Y.; Braun§, W. Effects of Backbone Contacts 3 'to the Abasic Site on the Cleavage and the Product Binding by Human Apurinic/Apyrimidinic Endonuclease (APE1). Biochemistry 2003, 43, 684-689. [CrossRef]

126. Hegde, M.; Izumi, T.; Mitra, S. Oxidized Base Damage and Single-Strand Break Repair in Mammalian Genomes. Prog. Mol. Biol. Transl. Sci. 2012, 110, 123-153. [CrossRef] [PubMed]

127. Fleming, A.M.; Burrows, C.J. 8-Oxo-7,8-dihydroguanine, friend and foe: Epigenetic-like regulator versus initiator of mutagenesis. DNA Repair 2017, 56, 75-83. [CrossRef] [PubMed] 
128. Fleming, A.M.; Burrows, C.J. On the irrelevancy of hydroxyl radical to DNA damage from oxidative stress and implications for epigenetics. Chem. Soc. Rev. 2020, 49, 6524-6528. [CrossRef] [PubMed]

129. Fleming, A.M.; Ding, Y.; Burrows, C.J. Oxidative DNA damage is epigenetic by regulating gene transcription via base excision repair. Proc. Natl. Acad. Sci. USA 2017, 114, 2604-2609. [CrossRef] [PubMed]

130. Roychoudhury, S.; Pramanik, S.; Harris, H.L.; Tarpley, M.; Sarkar, A.; Spagnol, G.; Sorgen, P.L.; Chowdhury, D.; Band, V.; Klinkebiel, D.; et al. Endogenous oxidized DNA bases and APE1 regulate the formation of G-quadruplex structures in the genome. Proc. Natl. Acad. Sci. USA 2020, 117, 11409-11420. [CrossRef]

131. Pan, L.; Wang, H.; Luo, J.; Zeng, J.; Pi, J.; Liu, H.; Liu, C.; Ba, X.; Qu, X.; Xiang, Y.; et al. Epigenetic regulation of TIMP1 expression by 8-oxoguanine DNA glycosylase-1 binding to DNA:RNA hybrid. FASEB J. 2019, 33, 14159-14170. [CrossRef]

132. Hao, W.; Qi, T.; Pan, L.; Wang, R.; Zhu, B.; Aguilera-Aguirre, L.; Radak, Z.; Hazra, T.K.; Vlahopoulos, S.; Bacsi, A.; et al. Effects of the stimuli-dependent enrichment of 8-oxoguanine DNA glycosylase1 on chromatinized DNA. Redox Biol. 2018, 18, 43-53. [CrossRef]

133. Ba, X.; Boldogh, I. 8-Oxoguanine DNA glycosylase 1: Beyond repair of the oxidatively modified base lesions. Redox Biol. 2017, 14, 669-678. [CrossRef]

134. Wang, R.; Hao, W.; Pan, L.; Boldogh, I.; Ba, X. The roles of base excision repair enzyme OGG1 in gene expression. Cell. Mol. Life Sci. 2018, 75, 3741-3750. [CrossRef] [PubMed]

135. Ba, X.; Aguilera-Aguirre, L.; Rashid, Q.T.A.N.; Bacsi, A.; Radak, Z.; Sur, S.; Hosoki, K.; Hegde, M.L.; Boldogh, I. The Role of 8-Oxoguanine DNA Glycosylase-1 in Inflammation. Int. J. Mol. Sci. 2014, 15, 16975-16997. [CrossRef]

136. Clark, D.W.; Phang, T.; Edwards, M.G.; Geraci, M.W.; Gillespie, M.N. Promoter G-quadruplex sequences are targets for base oxidation and strand cleavage during hypoxia-induced transcription. Free. Radic. Biol. Med. 2012, 53, 51-59. [CrossRef] [PubMed]

137. Pastukh, V.; Roberts, J.T.; Clark, D.W.; Bardwell, G.C.; Patel, M.; Al-Mehdi, A.-B.; Borchert, G.M.; Gillespie, M.N. An oxidative DNA "damage" and repair mechanism localized in the VEGF promoter is important for hypoxia-induced VEGF mRNA expression. Am. J. Physiol. Cell. Mol. Physiol. 2015, 309, L1367-L1375. [CrossRef] [PubMed]

138. Lemes, R.M.R.; Costa, A.J.; Bartolomeo, C.S.; Bassani, T.B.; Nishino, M.S.; Pereira, G.J.d.S.; Smaili, S.S.; Maciel, R.M.D.B.; Braconi, C.T.; da Cruz, E.F.; et al. 17ß-estradiol reduces SARS-CoV-2 infection in vitro. Physiol. Rep. 2021, 9, e14707. [CrossRef] [PubMed]

139. Erfinanda, L.; Ravindran, K.; Kohse, F.; Gallo, K.; Preissner, R.; Walther, T.; Kuebler, W.M. Oestrogen-mediated upregulation of the Mas receptor contributes to sex differences in acute lung injury and lung vascular barrier regulation. Eur. Respir. J. 2020, 57, 2000921. [CrossRef] [PubMed]

140. Perillo, B.; Ombra, M.N.; Bertoni, A.; Cuozzo, C.; Sacchetti, S.; Sasso, A.; Chiariotti, L.; Malorni, A.; Abbondanza, C.; Avvedimento, E.V. DNA Oxidation as Triggered by H3K9me2 Demethylation Drives Estrogen-Induced Gene Expression. Science 2008, 319, 202-206. [CrossRef] [PubMed]

141. Amente, S.; Bertoni, A.; Morano, A.; Lania, L.; Avvedimento, E.V.; Majello, B. LSD1-mediated demethylation of histone H3 lysine 4 triggers Myc-induced transcription. Oncogene 2010, 29, 3691-3702. [CrossRef] [PubMed]

142. Zuchegna, C.; Aceto, F.; Bertoni, A.; Romano, A.; Perillo, B.; Laccetti, P.; Gottesman, M.E.; Avvedimento, E.V.; Porcellini, A. Mechanism of retinoic acid-induced transcription: Histone code, DNA oxidation and formation of chromatin loops. Nucleic Acids Res. 2014, 42, 11040-11055. [CrossRef]

143. Donley, N.; Jaruga, P.; Coskun, E.; Dizdaroglu, M.; McCullough, A.K.; Lloyd, R.S. Small Molecule Inhibitors of 8-Oxoguanine DNA Glycosylase-1 (OGG1). ACS Chem. Biol. 2015, 10, 2334-2343. [CrossRef] [PubMed]

144. Tahara, Y.; Auld, D.; Ji, D.; Beharry, A.A.; Kietrys, A.M.; Wilson, D.L.; Jimenez, M.; King, D.; Nguyen, Z.; Kool, E.T. Potent and Selective Inhibitors of 8-Oxoguanine DNA Glycosylase. J. Am. Chem. Soc. 2018, 140, 2105-2114. [CrossRef] [PubMed]

145. Tahara, Y.-K.; Kietrys, A.M.; Hebenbrock, M.; Lee, Y.; Wilson, D.L.; Kool, E. Dual Inhibitors of 8-Oxoguanine Surveillance by OGG1 and NUDT1. ACS Chem. Biol. 2019, 14, 2606-2615. [CrossRef] [PubMed]

146. Qin, S.; Lin, P.; Wu, Q.; Pu, Q.; Zhou, C.; Wang, B.; Gao, P.; Wang, Z.; Gao, A.; Overby, M.; et al. Small-Molecule Inhibitor of 8-Oxoguanine DNA Glycosylase 1 Regulates Inflammatory Responses during Pseudomonas aeruginosa Infection. J. Immunol. 2020, 205, 2231-2242. [CrossRef]

147. Visnes, T.; Cázares-Körner, A.; Hao, W.; Wallner, O.; Masuyer, G.; Loseva, O.; Mortusewicz, O.; Wiita, E.; Sarno, A.; Manoilov, A.; et al. Small-molecule inhibitor of OGG1 suppresses proinflammatory gene expression and inflammation. Science 2018, 362, 834-839. [CrossRef]

148. Samson, L.D. A target to suppress inflammation. Science 2018, 362, 748-749. [CrossRef] 